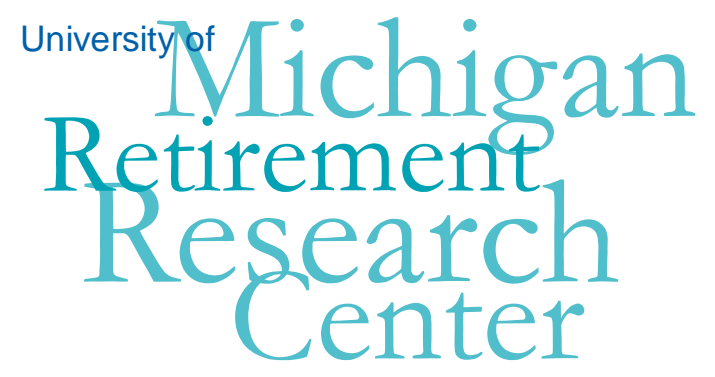

Working Paper

WP 2010-240

\title{
The Social Security Early Retirement Benefit as Safety Net
}

John Bound and Timothy Waidmann

\begin{tabular}{|l|l|}
\hline $\mathrm{M}$ & $\mathrm{R}$ \\
\hline $\mathrm{R}$ & $\mathrm{C}$ \\
\hline
\end{tabular}

Project \#: UM10-02 


\title{
The Social Security Early Retirement Benefit as Safety Net
}

\author{
John Bound \\ University of Michigan and National Bureau of Economic Research \\ Timothy Waidmann \\ The Urban Institute
}

October 2010

\author{
Michigan Retirement Research Center \\ University of Michigan \\ P.O. Box 1248 \\ Ann Arbor, MI 48104 \\ http://www.mrrc.isr.umich.edu/ \\ (734) 615-0422
}

\section{Acknowledgements}

This work was supported by a grant from the Social Security Administration through the Michigan Retirement Research Center (Grant \# 10-M-98362-5-01). The findings and conclusions expressed are solely those of the author and do not represent the views of the Social Security Administration, any agency of the Federal government, or the Michigan Retirement Research Center.

\section{Regents of the University of Michigan}

Julia Donovan Darrow, Ann Arbor; Laurence B. Deitch, Bingham Farms; Denise Ilitch, Bingham Farms; Olivia P. Maynard, Goodrich; Andrea Fischer Newman, Ann Arbor; Andrew C. Richner, Grosse Pointe Park; S. Martin

Taylor, Gross Pointe Farms; Katherine E. White, Ann Arbor; Mary Sue Coleman, ex officio 


\title{
The Social Security Early Retirement Benefit as Safety Net
}

\begin{abstract}
In this paper we used the Health and Retirement Study to examine the health and economic status of those who collect Social Security retirement benefits prior to the full retirement age. We used a propensity score reweighting method to estimate the fraction of early retirees who use early retirement benefits as a safety net against deteriorating health and who might be induced to apply for disability benefits (SSDI) or retire without income replacement if the generosity or availability of early retirement benefits were reduced. We find that while the majority of early retirees would likely not qualify for disability benefits, approximately one in five have health characteristics similar to SSDI beneficiaries, and thus might not be able to replace losses in benefit income with labor income.
\end{abstract}

\section{Authors’ Acknowledgements}

The research reported herein was pursuant to a grant from the U.S. Social Security Administration (SSA) funded as part of the Retirement Research Consortium (RRC). The findings and conclusions expressed are solely those of the authors and do not represent the views of SSA, any agency of the Federal Government or the Michigan Retirement Research Center. 
As the baby boom generation begin to retire and fiscal pressures from entitlement programs become more acute, evidence of improving health and increasing life expectancy in these cohorts has led many to suggest taking advantage of improved work capacity among older adults by increasing age requirements for the Social Security and Medicare programs. Currently, however, more than half of workers start receiving Social Security benefits before they reach full retirement age, and many of those who do are in relatively poor health. Data from the 1990 Census show that roughly one half of men and one third of women out of the workforce at age 62 identify themselves as having a health condition that limits their ability to work (Bound et al. 2000). While the health of the average 62 year old may well have improved, policies that reduce availability of benefits (e.g., raising the early retirement age), or reduce their value (raising the full retirement age, thereby reducing monthly benefits for early retirees) will affect both the healthy and unhealthy alike. The purpose of this paper is to systematically investigate the extent to which the availability of early social security benefits provides a safety net for those in poor health, who are either not in poor enough health to be eligible for disability benefits or who, for whatever reason, did not apply for them.

The estimation strategy compares the distributions of observable characteristics between those who receive such benefits and those who don't. The larger the degree of overlap in these distributions, the larger the fraction of non-recipients who might be eligible. One important policy implication of this estimate is that a larger potentially eligible pool among non-recipients would reduce the desired labor force participation response to an increase in eligibility age. A further implication of finding a large amount of overlap in these distributions is that an increased eligibility age for retirement benefits could induce an increased rate of application for DI benefits. 


\section{Data and Methods}

We used pooled data from the 1992-2006 waves of the Health and Retirement Study and stratified respondents into 4 categories: (a) those who reach that age of 62 and are receiving benefits through Social Security Disability Insurance (DI) or Supplemental Security Income (SSI); (b) those who reach the age of 62 and immediately start receiving early retirement benefits, (c) those who start receiving social security benefits after they would first qualify for them, but before full retirement age, and (d) those who start receiving such benefits when they reach full retirement age. Then for each respondent, using the last survey interview prior to their $63^{\text {rd }}$ birthday (hereafter called the "reference interview"), we define an extensive set of demographic, economic and health characteristics.

We first estimated a logit model of DI/SSI participation $\left(D I_{i}\right)$ prior to age 62 using observable characteristics $\left(X_{i}\right)$ as of the reference interview. That is, we estimate a maximum likelihood model of the form

$$
\operatorname{Prob}\left(D I_{i}\right)=\frac{e^{X_{i} \beta}}{1+e^{X_{i} \beta}}
$$

The individual characteristics in $X$ include basic demographic information (race/ethnicity, education and marital status), and detailed indicators of disease prevalence, limitations of physical function, and a measure of general health status. Models were estimated separately by gender. We also tested an alternative specification for the probability model that also included a variable indicating that the respondent reports a health-related limitation in their ability to work.

Using the estimated coefficients $(\hat{\beta})$ from these models, we calculated a DI-eligibility propensity score for each individual, $\hat{P}_{i}=e^{X_{i} \widehat{\beta}} /\left(1+e^{X_{i} \widehat{\beta}}\right)$. We first used these propensity scores to estimate the amount of overlap in the distributions of DI eligibility. In particular, we calculated the percentage of the non-DI population with DI propensity scores higher than fixed percentiles $\left(1^{\text {st }}, 5^{\text {th }}, 10^{\text {th }}, 25^{\text {th }} \& 50^{\text {th }}\right)$ of the 
DI beneficiary group. We also used these scores to create two alternative definitions of SSDI-eligibility. The more generous definition classified those with propensity scores above the $10^{\text {th }}$ percentile of DI beneficiaries as DI-eligible. The more restrictive definition used the $25^{\text {th }}$ percentile as the eligibility threshold.

In order to investigate the extent to which retirement age choices differed by the likelihood of DI eligibility, we reweighted the non-DI sample in two ways (DiNardo, et al. 1996; Barsky, et al., 2002). The first multiplies the HRS sampling weights by the factor $\gamma=\frac{\hat{P}_{i}}{1-\widehat{P}_{i}} * \frac{1-\bar{P}}{\bar{P}}$ and generates a subsample on non-beneficiaries that has a distribution of characteristics most similar to DI beneficiaries. The second, multiplying by $1 / \gamma$, generates a subsample that is least similar to the DI beneficiaries. We then compare the distribution of retirement ages between these two reweighted samples.

\section{Results}

Table 1 presents descriptive statistics on the four populations (stratified by DI status and retirement age) for men and for women. Among both men and women, we found that DI beneficiaries were more likely to be non-white, more likely to have low levels educational attainment, and less likely to be married than those who collect Social Security retirement benefits after age 62. Not surprisingly, across many measures, DI beneficiaries are in significantly worse health at age 62 than the average respondent who does not receive DI benefits. These measures include multiple indicators of diagnosed chronic disease, the prevalence of non-specific symptoms (back and foot problems, frequent pain), limitations of physical function, general health status and self-reported limitations in the ability to work. In terms of economic resources, those on DI are significantly disadvantaged in both household income (from nonsocial security sources) and financial wealth. 
While the availability of sufficient resources may allow earlier retirement, other things equal, the comparison of non-DI retirees by their age of collecting benefits suggests something different. First, especially among men, those who collected retirement benefits sooner had lower average income and assets. Consistent with the hypothesis that those in relatively poor health use early retirement benefits to offset the income loss associated with poor health, the data suggest that if there is a pattern, early retirees tend to be in worse health than those who wait until the full retirement age to collect benefits.

In order to estimate which recipients of retirement benefits were in poor enough health to be qualify for DI benefits, we used these observable characteristics to calculate a propensity score for DI eligibility for each individual based on their characteristics as measured at age $62 .{ }^{1}$ Figure 1 presents the distributions of the natural log of the odds ratio $\left(X_{i} \hat{\beta}\right)$ for the DI group and the three non-DI groups. As expected, the scores for those on DI are higher for both men and women, but there is substantial overlap in the distributions, especially for women. For men, a comparison of the distributions of the three non-DI groups shows that earlier retirees have higher DI scores than those who wait until their full retirement age to collect Social Security. For women, the patterns are less clear, however.

Table 2 presents a summary of these comparisons. For each group of retirees, we calculated the fraction of the group who would, based on DI propensity scores, be at least at "eligible" for DI as the person at the $1^{\text {st }}, 5^{\text {th }}, 10^{\text {th }}, 25^{\text {th }}$, and $50^{\text {th }}$ percentiles of the score distribution among $\mathrm{DI}$ beneficiaries. For men, while there is a substantial overlap in the distributions, between 30 and 40 percent of the non-DI groups would be in the bottom 5 percent of the score distribution of DI beneficiaries. Half to $65 \%$ would be in the lowest 10 percent, and 80 to 90 percent would be in the lowest quarter of the distribution. On

\footnotetext{
${ }^{1}$ Logit estimates used to calculate propensity scores for DI eligibility are presented in Table A1.
} 
the other hand, this still leaves $18 \%$ of the men who collect retirement benefits as early as possible who would be firmly in the heart of the DI distribution, and 6\% who score higher than the median DI beneficiary. In contrast, the men who wait until their full retirement age to begin receiving benefits are significantly less likely to score as highly on this scale. The same pattern by age at receiving retirement benefits does not hold for women. Regardless of the threshold, women who waited until their full retirement age were more likely to qualify for DI benefits when they were 62 than those who started receiving those benefits at the earliest possible date.

In table 3 we use the $25^{\text {th }}$ percentile of the male DI beneficiary score distribution to define the segment of the non-DI groups most likely to be DI eligible, and examine the characteristics of this group, relative to both actual DI beneficiaries and the low-propensity-score group. As indicated in table 2, this high propensity group constitutes $18 \%$ of those who began collecting retirement benefits as early as possible, and $12 \%$ of those who began collecting benefits at older ages. Within this group, the subgroup of most interest is made up of those who took retirement benefits as early as possible. On nearly every measure, this average man in this group was in similar or worse health than the average DI beneficiary when they were 62. In addition, they had similar levels of income and wealth and had comparable demographic characteristics to DI beneficiaries. Thus, it is not difficult to imagine that this subgroup of early retirees would be likely to apply for DI benefits if the early retirement benefit were not available. Compared to men who retired the earliest, the high-propensity men who waited to receive retirement benefits appear to have had greater access to economic resources, both through income and wealth and through the presence of a spouse. Health status at age 62 , however, was not generally better than the earliest retirees. Perhaps most importantly, the high propensity groups look more like DI recipients than like their lower-propensity counterparts (shown in the rightmost columns of the table), regardless of age. 
Table 4 shows the same calculations for women, and paints a similar picture of a subset of non-DI recipients who look very similar to DI beneficiaries. The most important difference between men and women is the higher share of women not receiving DI benefits who appear to be eligible for the program. This difference is most striking among women who waited until their full retirement age to begin receiving benefits, $41 \%$ of whom (table 2 ) appear to be eligible on the basis of their observable characteristics, compared to $12 \%$ of men who waited until full retirement age. This difference suggests a different set of decisions about when to retire between men and women. One possible explanation is the very high percentage of high-DI-propensity/late retiree women who are not married. This suggests that these women remain in the labor force in spite of poor health status because spousal income is not available to compensate for the income that would be foregone in retirement.

Finally, in table 5, we calculate the distribution of retirement age among non-DI beneficiaries using propensity reweighting to generate two complementary samples. The "eligible" subsample, by construction, has a distribution of health and demographic characteristics (as measured at age 62) that closely matches DI beneficiaries, while the "ineligible" subsample contains the remainder of the nonbeneficiaries. In the top right panel, the retirement age distribution of DI-eligible men is substantially younger than the distribution of ineligible men. $65 \%$ of eligible men choosing to collect retirement benefits at the earliest possible date, while less than half of ineligible men do the same. The differences for single men are even more stark. For women, we do not find a substantial difference between the eligible and ineligible subsamples when we look at both married and unmarried women. However, among single women, about half of the DI eligible sample collects benefits at the earliest age while less than one third of ineligible women do the same. 


\section{Discussion}

Some analysts have used evidence of improving functional health of the elderly and near-elderly to support proposals to raise the full (and early) retirement ages for Social Security (Liebman et al. 2005; Mermin and Steuerle 2006). The group most likely to be adversely affected by such a change are those who use early retirement as a safety net when declining health compromises their ability to work. In order to more fully evaluate this policy option, it is necessary to estimate the size of this group. If a substantial portion of early retirees look very much like those who qualified for $\mathrm{DI} / \mathrm{SSI}$, there is likely to be an increase in $\mathrm{DI} / \mathrm{SSI}$ applications, as the most disabled early retirees seek to replace lost income. The larger this group, the larger the welfare loss from added costs of the application process for both the applicant the government, and from classification errors created by imperfect screening of work capacity. Further, to the extent that early retirees successfully apply for $\mathrm{DI} / \mathrm{SSI}$, there will also be a smaller fiscal savings from unpaid benefits. In fact, because the DI benefit is actuarially more generous, payments for successful applicants will actually increase. To the extent that these workers do not meet the medical eligibility criteria for DI, but are still limited in their ability to work, an increased retirement age may induce workers to remain in jobs beyond the point where their reduced productivity warrants. Conversely, to the extent early retirees are largely those with the financial wherewithal to forego earnings, the more attractive are proposals to raise eligibility ages.

The analyses completed to this point suggest several preliminary conclusions. First, while the average early retiree is in better health than the average DI recipient, there are a notable fraction of early retirees who are observationally undistinguishable from DI recipients. For these people, eliminating their ability to collect on their retirement benefits at age 62 could result in their applying for DI benefits. Those who are successful would collect higher benefits from SSA, and those who are denied may still be too impaired to work. For men, early retirees look more like DI recipients than later retirees, lending support to the hypothesis that some use ER benefit as a safety net against failing 
health. Women who use early retirement, on the other hand, appear to be healthier. More importantly, they are married. An analysis restricted to single women (not shown) has dramatically different findings. Nearly half of women taking early retirement benefits meet the $25^{\text {th }}$ percentile criterion for simulated DI eligibility, while only $28 \%$ of women who waited to full retirement age have propensity scores this high. Thus, the reversal between men and women in the correlation between health and early retirement appears to be an artifact of differences in retirement behavior linked to marital status. Single women in relatively poor health would thus be most negatively affected by changes in retirement age policies.

Directions for future analysis. To date we have analyzed only self-reported data from the HRS. In addition to these analyses, we hope to be able to compare information on the Social Security Administration's 831 files-which include administrative information on those who apply for DI or SSI disability benefits - to the information available from HRS respondents. While we and other researchers have used the HRS respondents self-reports on their application for disability benefits, there is reason to believe that the information obtained from such reports may not be reliable. Indeed, there is reason to worry that respondents who have applied for DI or SSI benefits and had their applications denied may not always report this fact. The relatively few HRS respondents who report that they have applied for DI or SSI benefits but having these applications denied certainly suggests that this might be the case. 


\section{References}

Barsky, Robert B., Bound, John, Charles, Kerwin Kofi and Lupton, Joseph P. 2002. "Accounting for the Black-White Wealth Gap: A Nonparametric Approach," Journal of the American Statistical Association 97(459):663-673.

Bound, John, Michael Schoenbaum and Timothy Waidmann. 2000. "Health Limitations and Early Retirement," Michigan Retirement Research Center Issue Brief 2000-Q2, September 2000.

http://www.mrrc.isr.umich.edu/publications/briefs/pdf/ib_99Q2.pdf

DiNardo, John, Nicole M. Fortin and Thomas Lemieux. 1996. "Labor Market Institutions and the Distribution of Wages, 1973-1992: A Semiparametric Approach," Econometrica 64(5):1001-1044.

Liebman, Jeffrey, Maya MacGuineas, and Andrew Samwick. 2005. “Nonpartisan Social Security Reform Plan," New America Foundation Policy Paper, December 2005. http://www.newamerica.net/files/archive/Doc_File_2757_1.pdf

Mermin, Gordon B.T., and C. Eugene Steuerle. 2006 "Would Raising the Social Security Retirement Age Harm Low-income Groups?" Urban Institute Retirement Project Brief, December 2006. http://www.urban.org/UploadedPDF/311413_Raising_Retirement_Age.pdf 


\begin{tabular}{|c|c|c|c|c|c|c|c|c|}
\hline \multirow[b]{3}{*}{ Characteristics at age $62^{*}$} & \multicolumn{4}{|c|}{ Men } & \multicolumn{4}{|c|}{ Women } \\
\hline & \multirow{2}{*}{$\begin{array}{c}\text { SSDI } \\
\text { beneficiaries }\end{array}$} & \multicolumn{3}{|c|}{ First receipt of SS benefits } & \multirow{2}{*}{$\begin{array}{c}\text { SSDI } \\
\text { beneficiaries }\end{array}$} & \multicolumn{3}{|c|}{ First receipt of SS benefits } \\
\hline & & 62 & 63 - FRA & FRA & & 62 & $63-F R A$ & FRA \\
\hline \multicolumn{9}{|l|}{ Demographic Characteristics } \\
\hline Black & 0.128 & 0.079 & 0.079 & 0.059 & 0.148 & 0.059 & 0.064 & 0.085 \\
\hline Hispanic & 0.068 & 0.047 & 0.048 & 0.051 & 0.075 & 0.042 & 0.060 & 0.047 \\
\hline Less than High School & 0.344 & 0.216 & 0.196 & 0.157 & 0.333 & 0.168 & 0.172 & 0.150 \\
\hline College Graduate & 0.084 & 0.217 & 0.223 & 0.331 & 0.092 & 0.134 & 0.233 & 0.267 \\
\hline Unmarried/partnered & 0.241 & 0.147 & 0.094 & 0.104 & 0.488 & 0.107 & 0.171 & 0.373 \\
\hline \multicolumn{9}{|l|}{ Chronic Disease Prevalence } \\
\hline Hypertension & 0.573 & 0.445 & 0.423 & 0.342 & 0.520 & 0.438 & 0.394 & 0.356 \\
\hline Diabetes & 0.262 & 0.135 & 0.110 & 0.085 & 0.179 & 0.095 & 0.108 & 0.073 \\
\hline Cancer & 0.102 & 0.069 & 0.066 & 0.047 & 0.125 & 0.110 & 0.075 & 0.074 \\
\hline Lung disease & 0.183 & 0.059 & 0.067 & 0.031 & 0.171 & 0.067 & 0.070 & 0.061 \\
\hline Heart Disease & 0.433 & 0.329 & 0.290 & 0.295 & 0.311 & 0.265 & 0.198 & 0.287 \\
\hline Stroke & 0.129 & 0.024 & 0.031 & 0.031 & 0.072 & 0.028 & 0.020 & 0.032 \\
\hline Psych & 0.229 & 0.069 & 0.058 & 0.048 & 0.300 & 0.129 & 0.107 & 0.079 \\
\hline Arthritis & 0.611 & 0.427 & 0.449 & 0.368 & 0.684 & 0.545 & 0.549 & 0.521 \\
\hline Back problem & 0.457 & 0.265 & 0.269 & 0.269 & 0.439 & 0.278 & 0.289 & 0.206 \\
\hline Foot problem & 0.294 & 0.112 & 0.131 & 0.083 & 0.279 & 0.156 & 0.134 & 0.150 \\
\hline Frequent Pain & 0.490 & 0.208 & 0.213 & 0.138 & 0.430 & 0.241 & 0.231 & 0.213 \\
\hline \multicolumn{9}{|l|}{ Other Health Measures } \\
\hline Upper Body Limitation & 0.519 & 0.160 & 0.131 & 0.100 & 0.538 & 0.254 & 0.254 & 0.227 \\
\hline Lower Body Limitation & 0.769 & 0.446 & 0.444 & 0.302 & 0.731 & 0.596 & 0.539 & 0.526 \\
\hline Fair/Poor Health & 0.567 & 0.156 & 0.139 & 0.083 & 0.439 & 0.131 & 0.136 & 0.085 \\
\hline Work Limitation & 0.741 & 0.154 & 0.104 & 0.080 & 0.532 & 0.197 & 0.136 & 0.058 \\
\hline \multicolumn{9}{|l|}{ Economic Resources } \\
\hline Non-Social Security Income & 17,641 & 42,850 & 62,359 & 94,819 & 20,306 & 27,064 & 41,178 & 47,761 \\
\hline Non-Housing Assets & 96,700 & 224,464 & 295,266 & 388,498 & 147,644 & 257,804 & 267,521 & 220,409 \\
\hline Ever applied for DI & & 0.052 & 0.031 & 0.009 & & 0.045 & 0.043 & 0.019 \\
\hline
\end{tabular}

*Characteristics measured at last interview before 63rd birthday

Source: Authors tabulations based on 1992-2006 Health and Retirement Study 
Table 2: Distribution of predicted SSDI eligibility compared to distribution of SSDI recipients, by age at retirement

\begin{tabular}{|c|c|c|c|c|c|c|c|c|}
\hline \multirow[b]{6}{*}{ PS $>1$ st \%ile of DI dist } & \multicolumn{4}{|c|}{ Men } & \multicolumn{4}{|c|}{ Women } \\
\hline & \multirow{3}{*}{$\begin{array}{c}\text { SSDI } \\
\text { beneficiaries }\end{array}$} & \multicolumn{3}{|c|}{ First receipt of SS benefits } & \multirow{3}{*}{$\begin{array}{c}\text { SSDI } \\
\text { beneficiaries }\end{array}$} & \multicolumn{3}{|c|}{ First receipt of SS benefits } \\
\hline & & & & & & & & \\
\hline & & 62 & 63 - FRA & FRA & & 62 & 63 - FRA & FRA \\
\hline & \multicolumn{8}{|c|}{ Percent with propensity scores greater than threshhold } \\
\hline & $99 \%$ & $86 \%$ & $88 \%$ & $78 \%$ & $99 \%$ & $92 \%$ & $90 \%$ & $95 \%$ \\
\hline PS $>5$ th \%ile of DI dist & $95 \%$ & $72 \%$ & $71 \%$ & $59 \%$ & $95 \%$ & $81 \%$ & $76 \%$ & $82 \%$ \\
\hline PS $>10$ th \%ile of DI dist & $90 \%$ & $52 \%$ & $52 \%$ & $35 \%$ & $90 \%$ & $61 \%$ & $59 \%$ & $63 \%$ \\
\hline PS $>25$ th \%ile of DI dist & $75 \%$ & $18 \%$ & $12 \%$ & $12 \%$ & $75 \%$ & $25 \%$ & $29 \%$ & $41 \%$ \\
\hline PS $>50$ th \%ile of DI dist & $50 \%$ & $6 \%$ & $4 \%$ & $2 \%$ & $50 \%$ & $8 \%$ & $12 \%$ & $10 \%$ \\
\hline
\end{tabular}

Source: Authors tabulations based on 1992-2006 HRS. 
Table 3: Select Characteristics by actual and imputed DI eligibility status, men

\begin{tabular}{|c|c|c|c|c|c|c|c|}
\hline \multirow[b]{3}{*}{ Characteristics (at 62) } & \multirow[b]{3}{*}{$\begin{array}{c}\text { SSDI } \\
\text { beneficiaries }\end{array}$} & \multicolumn{3}{|c|}{ DI-"eligible" (PS>=25th \%ile) } & \multicolumn{3}{|c|}{$\begin{array}{c}\text { DI-"ineligible" (PS<25th } \\
\text { \%ile) }\end{array}$} \\
\hline & & \multicolumn{6}{|c|}{ First receipt of SS benefits } \\
\hline & & 62 & $\begin{array}{l}63- \\
\text { FRA } \\
\end{array}$ & FRA & 62 & $\begin{array}{l}63- \\
\text { FRA }\end{array}$ & FRA \\
\hline Non-white & 0.215 & 0.293 & 0.219 & 0.185 & 0.115 & 0.133 & 0.119 \\
\hline Less than High School & 0.344 & 0.381 & 0.287 & 0.342 & 0.179 & 0.183 & 0.133 \\
\hline College Graduate & 0.084 & 0.060 & 0.000 & 0.032 & 0.252 & 0.254 & 0.369 \\
\hline Unmarried/partnered & 0.241 & 0.258 & 0.159 & 0.128 & 0.122 & 0.084 & 0.100 \\
\hline Diabetes & 0.262 & 0.288 & 0.141 & 0.315 & 0.101 & 0.106 & 0.055 \\
\hline Heart Disease & 0.433 & 0.408 & 0.453 & 0.461 & 0.312 & 0.268 & 0.273 \\
\hline Stroke & 0.129 & 0.095 & 0.111 & 0.176 & 0.009 & 0.019 & 0.013 \\
\hline Cancer & 0.102 & 0.078 & 0.187 & 0.058 & 0.067 & 0.050 & 0.046 \\
\hline Mental Illness & 0.229 & 0.194 & 0.217 & 0.099 & 0.041 & 0.035 & 0.042 \\
\hline Back Problem & 0.457 & 0.361 & 0.624 & 0.588 & 0.244 & 0.219 & 0.227 \\
\hline Upper body limitation & 0.519 & 0.512 & 0.410 & 0.349 & 0.082 & 0.092 & 0.068 \\
\hline Lower body limitation & 0.769 & 0.781 & 0.839 & 0.894 & 0.371 & 0.389 & 0.224 \\
\hline Fair/Poor Health & 0.567 & 0.627 & 0.637 & 0.551 & 0.051 & 0.070 & 0.022 \\
\hline Work Limitation* & 0.741 & 0.446 & 0.398 & 0.242 & 0.089 & 0.063 & 0.059 \\
\hline Ever Applied for DI* & & 0.233 & 0.055 & 0.075 & 0.012 & 0.027 & 0.000 \\
\hline Non-SS income* & 17,641 & 27,536 & 57,105 & 35,208 & 46,264 & 63,091 & 102,601 \\
\hline Non-housing Assets* & 96,700 & 113,375 & 223,781 & 134,037 & 249,227 & 305,225 & 421,720 \\
\hline
\end{tabular}

* not part of prediction

equation

Source: Authors' tabulations of 1992-2006 HRS. 
Table 4: Select Characteristics by actual and imputed DI eligibility status, women

\begin{tabular}{|c|c|c|c|c|c|c|c|}
\hline \multirow[b]{3}{*}{ Characteristics (at 62) } & \multirow[b]{3}{*}{$\begin{array}{c}\text { SSDI } \\
\text { beneficiaries }\end{array}$} & \multicolumn{3}{|c|}{$\begin{array}{c}\text { DI-"eligible" (PS>=25th } \\
\text { \%ile) }\end{array}$} & \multicolumn{3}{|c|}{$\begin{array}{c}\text { DI-"ineligible" (PS<25th } \\
\text { \%ile) }\end{array}$} \\
\hline & & \multicolumn{6}{|c|}{ First receipt of SS benefits } \\
\hline & & 62 & $\begin{array}{l}63- \\
\text { FRA }\end{array}$ & FRA & 62 & $\begin{array}{l}63- \\
\text { FRA }\end{array}$ & FRA \\
\hline Non-white & 0.250 & 0.238 & 0.260 & 0.255 & 0.081 & 0.091 & 0.137 \\
\hline Less than High School & 0.333 & 0.317 & 0.289 & 0.236 & 0.118 & 0.125 & 0.089 \\
\hline College Graduate & 0.092 & 0.078 & 0.092 & 0.257 & 0.153 & 0.289 & 0.274 \\
\hline Unmarried/partnered & 0.488 & 0.363 & 0.559 & 0.871 & 0.023 & 0.016 & 0.023 \\
\hline Diabetes & 0.179 & 0.185 & 0.122 & 0.101 & 0.066 & 0.102 & 0.053 \\
\hline Heart Disease & 0.311 & 0.273 & 0.235 & 0.258 & 0.262 & 0.184 & 0.307 \\
\hline Stroke & 0.072 & 0.073 & 0.027 & 0.063 & 0.013 & 0.018 & 0.010 \\
\hline Cancer & 0.125 & 0.180 & 0.095 & 0.068 & 0.087 & 0.066 & 0.079 \\
\hline Mental Illness & 0.300 & 0.316 & 0.267 & 0.077 & 0.067 & 0.043 & 0.080 \\
\hline Back Problem & 0.439 & 0.408 & 0.412 & 0.226 & 0.235 & 0.240 & 0.193 \\
\hline Upper body limitation & 0.538 & 0.540 & 0.525 & 0.250 & 0.160 & 0.147 & 0.211 \\
\hline Lower body limitation & 0.731 & 0.802 & 0.745 & 0.628 & 0.528 & 0.457 & 0.455 \\
\hline Fair/Poor Health & 0.439 & 0.460 & 0.400 & 0.134 & 0.022 & 0.030 & 0.050 \\
\hline Work Limitation* & 0.532 & 0.413 & 0.301 & 0.068 & 0.125 & 0.070 & 0.050 \\
\hline Ever Applied for DI* & & 0.150 & 0.125 & 0.045 & 0.010 & 0.011 & 0.000 \\
\hline Non-SS income* & 20,306 & 17,542 & 23,040 & 38,493 & 30,197 & 48,418 & 54,254 \\
\hline Non-housing Assets* & 147,644 & 121,511 & 80,289 & 111,914 & 302,636 & 342,261 & 296,422 \\
\hline
\end{tabular}

* not part of prediction

equation

Source: Authors' tabulations of 1992-2006 HRS. 
Table 5: Age at first receipt of Social Security Retirement Benefits, by simulated DI-eligibility status

\begin{tabular}{|c|c|c|c|c|c|c|c|}
\hline \multirow{3}{*}{ Men } & \multicolumn{3}{|c|}{ Men } & & \multicolumn{3}{|c|}{ Single Men } \\
\hline & \multirow[b]{2}{*}{ Actual } & \multicolumn{2}{|c|}{ Simulated DI eligibility } & & \multirow[b]{2}{*}{ Actual } & \multicolumn{2}{|c|}{ Simulated DI eligibility } \\
\hline & & eligible & ineligible & & & eligible & ineligible \\
\hline 62 & 50.6 & 65.0 & 47.7 & 62 & 59.8 & 84.1 & 51.1 \\
\hline 63-FRA & 28.3 & 21.5 & 26.7 & 63-FRA & 22.7 & 10.3 & 23.0 \\
\hline FRA & 21.1 & 13.5 & 25.6 & FRA & 17.6 & 5.6 & 25.9 \\
\hline \multirow{3}{*}{ Women } & \multicolumn{3}{|c|}{ Women } & & \multicolumn{3}{|c|}{ Single Women } \\
\hline & & \multicolumn{2}{|c|}{ Simulated DI eligibility } & & & \multicolumn{2}{|c|}{ Simulated DI eligibility } \\
\hline & Actual & eligible & ineligible & & Actual & eligible & ineligible \\
\hline 62 & 57.4 & 54.9 & 58.1 & 62 & 37.3 & 49.5 & 32.7 \\
\hline 63-FRA & 28.0 & 27.7 & 29.0 & 63-FRA & 29.6 & 21.8 & 26.6 \\
\hline FRA & 14.6 & 17.4 & 13.0 & FRA & 33.1 & 28.7 & 40.7 \\
\hline
\end{tabular}


Figure 1: Distributions of Expected SSDI eligibility, by retirement age
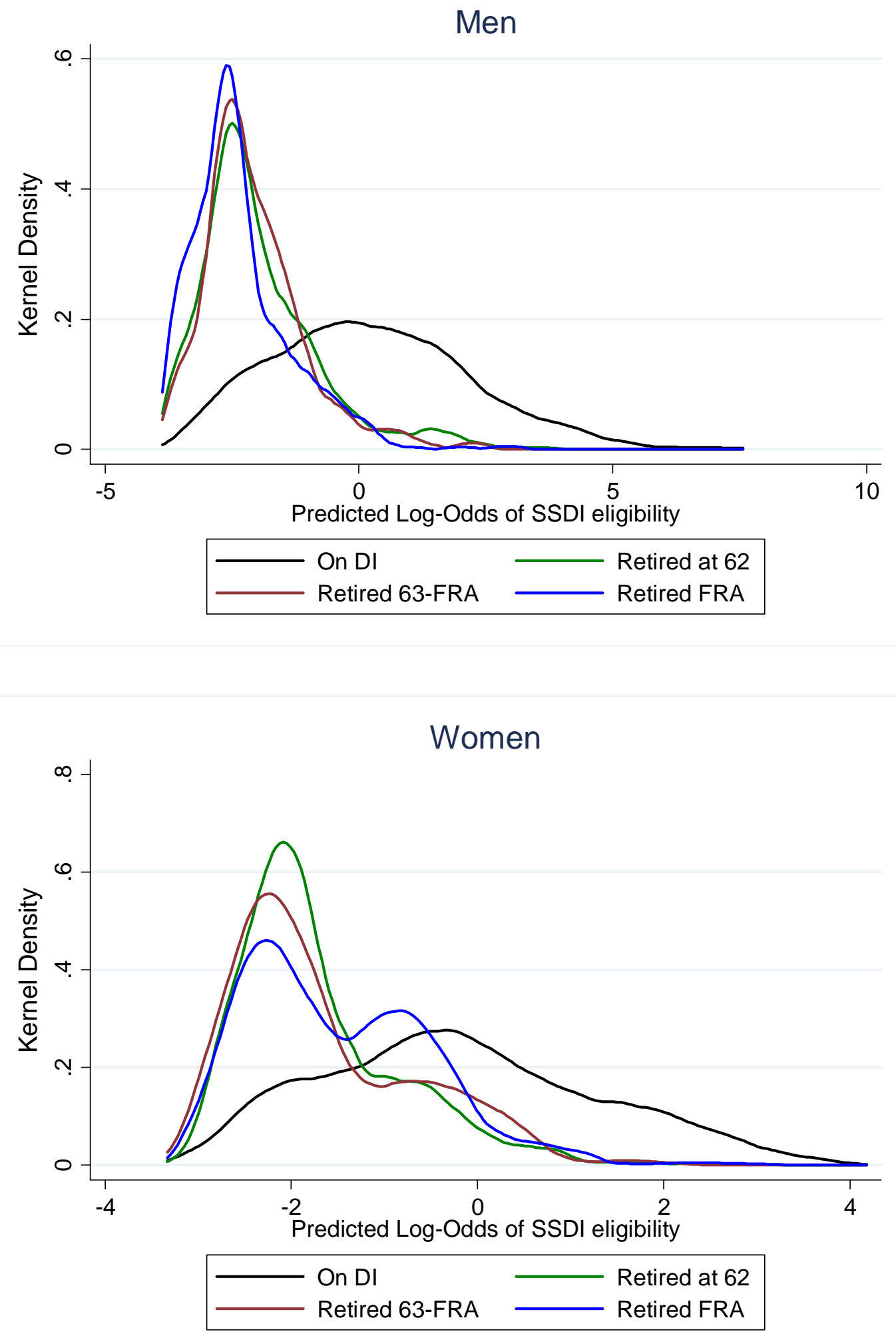
Table A1: Logit models of SSDI receipt before age 62

\begin{tabular}{|c|c|c|c|c|}
\hline \multirow[b]{2}{*}{ Characteristics at age $62^{*}$} & \multicolumn{2}{|c|}{ Men } & \multicolumn{2}{|c|}{ Women } \\
\hline & $\begin{array}{r}\text { Logit } \\
\text { coefficient }\end{array}$ & $z$-stat & $\begin{array}{r}\text { Logit } \\
\text { coefficient }\end{array}$ & z-stat \\
\hline \multicolumn{5}{|l|}{ Demographics } \\
\hline Black & 0.369 & 1.69 & 0.306 & 1.75 \\
\hline Other Non-Hispanic & 0.203 & 0.33 & 0.379 & 0.96 \\
\hline Hispanic & 0.022 & 0.08 & 0.090 & 0.39 \\
\hline Less than High School & 0.160 & 0.84 & 0.153 & 1.01 \\
\hline Some college & -0.236 & -1.06 & -0.423 & -2.39 \\
\hline College Graduate & -0.802 & -2.97 & -0.594 & -2.84 \\
\hline Separated or divorced & 0.754 & 3.37 & 1.602 & 11.68 \\
\hline Never married & 1.036 & 2.42 & 0.613 & 1.89 \\
\hline \multicolumn{5}{|l|}{ Chronic disease prevalence } \\
\hline Hypertension & -0.058 & -0.36 & -0.057 & -0.44 \\
\hline Diabetes & 0.559 & 2.75 & 0.082 & 0.46 \\
\hline Cancer & 0.180 & 0.62 & 0.285 & 1.5 \\
\hline Lung disease & 0.318 & 1.22 & -0.138 & -0.66 \\
\hline Heart Disease & -0.164 & -0.98 & -0.360 & -2.53 \\
\hline Stroke & 0.982 & 2.97 & 0.306 & 1.06 \\
\hline Psych & 0.721 & 2.99 & 0.599 & 3.65 \\
\hline Arthritis & 0.123 & 0.72 & 0.039 & 0.28 \\
\hline Back problem & 0.045 & 0.24 & -0.004 & -0.03 \\
\hline Foot problem & -0.163 & -0.75 & 0.089 & 0.57 \\
\hline Frequent Pain & 0.226 & 1.13 & -0.125 & -0.76 \\
\hline \multicolumn{5}{|c|}{ Level of difficulty with physical tasks } \\
\hline Jog 1 mile & 0.016 & 0.14 & -0.072 & -0.84 \\
\hline Walk several blocks & 0.396 & 2.68 & 0.312 & 2.7 \\
\hline Walk one block & 0.089 & 0.55 & 0.240 & 1.73 \\
\hline Walk across room & -0.356 & -1.51 & -0.057 & -0.27 \\
\hline Sit 2 hours & 0.007 & 0.06 & -0.017 & -0.18 \\
\hline Stand & -0.010 & -0.08 & -0.026 & -0.27 \\
\hline Get into/out of bed & -0.302 & -1.38 & -0.046 & -0.23 \\
\hline Go up stairs & 0.297 & 2.51 & -0.032 & -0.34 \\
\hline Go up one flight & -0.044 & -0.31 & 0.213 & 1.84 \\
\hline Lift 10 lbs & 0.214 & 1.59 & 0.155 & 1.55 \\
\hline Kneel & 0.061 & 0.52 & -0.068 & -0.73 \\
\hline Pick up dime & 0.068 & 0.44 & -0.036 & -0.29 \\
\hline Shower/Bathe & 0.041 & 0.16 & 0.233 & 1.15 \\
\hline Reach over head & 0.248 & 1.99 & 0.189 & 1.83 \\
\hline Push large object & 0.476 & 3.71 & 0.177 & 1.85 \\
\hline Feed self & 0.812 & 1.74 & -0.166 & -0.64 \\
\hline Dress self & 0.301 & 1.72 & 0.098 & 0.59 \\
\hline Fair or poor health & 0.876 & 4.81 & 0.675 & 3.98 \\
\hline Constant & -2.000 & -10.01 & -1.611 & -10.21 \\
\hline $\mathbf{N}$ & \multicolumn{2}{|c|}{1469} & \multicolumn{2}{|c|}{1914} \\
\hline Likelihood Ratio statistic (37 df) & \multicolumn{2}{|c|}{567.50} & \multicolumn{2}{|c|}{524.00} \\
\hline Pseudo $\mathbf{R}^{2}$ & \multicolumn{2}{|c|}{0.3370} & \multicolumn{2}{|c|}{0.2318} \\
\hline
\end{tabular}

*Characteristics measured at last interview before 63rd birthday

Source: Authors analysis of 1992-2006 HRS data. 